\title{
Seminal and spermatic characteristics of fresh semen and the effects of sperm cooling in Steindachneridion melanodermatum (Garavello, 2005)
}

\section{Características seminais e espermáticas e os efeitos do resfriamento de esperma do Steindachneridion melanodermatum (Garavello, 2005) sobre os parâmetros espermáticos.}

\author{
Ronan Maciel Marcos ${ }^{1}$; Giovano Neumann²; Cesar Pereira Rebechi de Toledo²; \\ João Marcos Sena²; Gilmar Baumgartner ${ }^{3}$; Robie Allan Bombardelli ${ }^{3}$
}

\begin{abstract}
This study describes the seminal and spermatic characteristics of fresh semen of Steindachneridion melanodermatum and investigates the effects of dilution, temperature, and storage period on its spermatic parameters. Sperm samples were collected from nine hormonally-induced males. The following parameters in fresh sperm were analyzed: seminal plasma osmolality (OSM), seminal pH, sperm motility (MOT), sperm velocity (SV) (including sperm curvilinear velocity (VCL), sperm straight-line velocity (VSL), and sperm average path velocity (VAP)), total time of sperm motility (TEMP), sperm concentration (CONC), and index of sperm normality (NORM). Sperm samples from each male were diluted in a solution containing $5 \%$ fructose and $5 \%$ powdered milk, and stored at $10^{\circ} \mathrm{C}$ and $25^{\circ} \mathrm{C}$. The same was carried out for sperm samples not subjected to dilution. From these samples, MOT, VCL, VSL, VAP, SV, and TEMP were measured after 0 h, 5 h, 9 h, 18 h, 27 h, 36 h, 45 h, and 54 h. Males released $11.74 \pm 5.38 \mathrm{~mL}$ of sperm, with an osmolality of $258.78 \pm 29.36 \mathrm{mOsm} \cdot \mathrm{kg}^{-1}$ and $\mathrm{pH}$ of $7.11 \pm 0.31$. The sperm presented a MOT of $99.86 \pm 0.31 \%$ at a concentration of $1.03 \times 10^{10} \pm 3.65 \times$ $10^{9}$ spermatozoa.mL ${ }^{-1}$ with VCL of $185.58 \pm 14.11 \mu \mathrm{m} . \mathrm{s}^{-1}$, VSL of $49.15 \pm 4.66 \mu \mathrm{m} . \mathrm{s}^{-1}$, VAP of $87.02 \pm$ $4.13 \mu \mathrm{m} . \mathrm{s}^{-1}, \mathrm{SV}$ of $106.52 \pm 4.45 \mu \mathrm{m} . \mathrm{s}^{-1}$, TEMP of $79.31 \pm 5.62 \mathrm{~s}$, NORM of $75.81 \pm 5.71 \%$. The results indicate that sperm motility, sperm velocity, and total time of sperm activation were affected by dilution, storage temperature, and storage period $(\mathrm{p}<0.05)$. Procedures for semen storage should be performed with undiluted sperm cooled at $10^{\circ} \mathrm{C}$, or kept undiluted at $25^{\circ} \mathrm{C}$ for up to $27 \mathrm{~h}$.
\end{abstract}

Key words: CASA, endemic, sperm characterization, sperm motility, sperm storage, sperm velocity

\section{Resumo}

O objetivo deste estudo foi descrever os parâmetros seminais e espermáticos no sêmen fresco do Steindachneridion melanodermatum e os efeitos da diluição, da temperatura e do tempo de estocagem do sêmen sobre os parâmetros espermáticos. Foi coletado o sêmen de nove machos, induzidos hormonalmente. No sêmen fresco foram avaliados os parâmetros: osmolaridade do plasma seminal (OSM), pH seminal (pH), motilidade (MOT) e velocidades espermáticas (VCL, VLR, VMD, VE),

\footnotetext{
${ }^{1}$ Mestre em Recursos Pesqueiros e Engenharia de Pesca, Professor Adjunto da Universidade Federal da Fronteira Sul, UFFS, Laranjeiras do Sul, PR, Brasil. E-mail: ronan.marcos@uffs.edu.br

2 Mestres em Recursos Pesqueiros e Engenharia de Pesca, discentes, Universidade Estadual do Oeste do Paraná, UNIOESTE, Toledo, PR. E-mail: giovanoneumann@hotmail.com; cprtoledo@gmail.com; marcos.wilham@gmail.com

3 Professores Doutores Adjuntos da Universidade Estadual do Oeste do Paraná, UNIOESTE, Toledo, PR. E-mail: gilmar_baum@ yahoo.com.br; rabombardelli@gmail.com

* Author for correspondence
} 
tempo total de motilidade espermática (TEMP), concentração espermática e índice de normalidade espermática (NORM). De cada macho, amostras de sêmen que foram diluídas em solução contendo 5\% de frutose e $5 \%$ de leite em pó e, armazenadas a 10 e $25^{\circ} \mathrm{C}$. O mesmo foi feito para amostras de sêmen não submetidas à diluição. Destas amostras, as MOT, VCL, VLR, VMD, VE, TEMP foram mensuradas após $0,5,9,18,27,36,45,54$ horas. Os machos liberaram $11,74 \pm 5,38 \mathrm{~mL}$ de sêmen com $258,78 \pm$ $29,36 \mathrm{mOsm} \cdot \mathrm{kg}^{-1}$ e pH de $7,11 \pm 0,31$. O sêmen apresentou $99,86 \pm 0,31 \%$ de MOT, com $1,03 \times 10^{10} \pm$ $3,65 \times 10^{9}$ espermatozódes.mL ${ }^{-1} \mathrm{e}, 185,58 \pm 14,11 \mu \mathrm{m} \cdot \mathrm{s}^{-1}$ para VCL, 49, $15 \pm 4,66 \mu \mathrm{m} \cdot \mathrm{s}^{-1}$ para VLR, 87,02 $\pm 4,13 \mu \mathrm{m} . \mathrm{s}^{-1}$ para VMD, $106,52 \pm 4,45 \mu \mathrm{m} . \mathrm{s}^{-1}$ para VE, 79,31 $\pm 5,62 \mathrm{~s}$ para TEMP e $75,81 \pm 5,71 \%$ de NORM. A motilidade, as velocidades e o tempo total de motilidade espermática foram influenciados $(p<0,05)$ pela diluição, pelas temperaturas e tempos de armazenamento. A estocagem do sêmen poderá ser realizado sem diluição e resfriado a $10^{\circ} \mathrm{C}$ ou sem diluição, a temperatura de $25^{\circ} \mathrm{C}$, pelo período de até 27 horas.

Palavras-chave: Caracterização seminal, CASA, endêmico, estocagem de sêmen, motilidade espermática, velocidade espermatica

\section{Introduction}

The Iguaçu sorubim, Steindachneridion melanodermatum (GARAVELLO, 2005), is a South American catfish, endemic to the Iguaçu River basin (FROESE; PAULY, 2014). It is carnivorous (ZANIBONI-FILHO et al., 2004), and reaches large sizes (length $<532 \mathrm{~mm}$ ) (GARAVELLO, 2005). This is a migratory species, which is subject to potential extinction (SUZUKI et al., 2003), and due to dams on the Iguaçu River, its current distribution is restricted to the stretches between hydroelectric plants (GARAVELLO, 2005). These facts and the lack of information regarding Steindachneridion reproductive biology (HONJI et al., 2012) suggest advanced research on their genetic variability (MATOSO et al., 2011) and artificial reproduction. Moreover, due to their growth characteristics and meat quality, research has been conducted to assess the nutritional aspects (LEWANDOWSKI et al., 2013) and its potential for rearing in net cages (FEIDEN et al., 2013).

The development of breeding techniques is the first step to enable artificial fish propagation (ROMAGOSA et al., 2010) and the formation of either in vivo or in vitro genetic banks (ZANIBONIFILHO; SCHULZ, 2003). However, there is no information regarding the reproductive features of $S$. melanodermatum in captivity, or efficient biotechnology tools for gamete manipulation and conservation. The few available reports provide superficial data regarding sperm release and some sperm traits (LUDWIG et al., 2005; SANT'ANNA, 2009).

Since seminal and spermatic parameters allow the rational utilization of high-quality gametes and superior broodstock identification (COWARD et al., 2002), they enable the development of efficient broodstock management by using adequate inseminating dosages (BOMBARDELLI et al., 2006; STREIT JÚNIOR et al., 2008), cryopreserved semen viability in artificial fertilization processes (SUQUET et al., 2000), and technology development for the formation of genetic banks (ZANIBONIFILHO; SCHULZ, 2003) directed to biodiversity conservation or genetic improvement programs.

The development of methods focusing on the conservation of male gametes in Neotropical fish has been intensively investigated (VIVEIROS et al., 2010), as the gametes quickly become unviable after ovulation or spermiation (RIZZO et al., 2003). Besides cryopreservation by freezing, semen storage techniques at low temperatures might favor gamete preservation over short periods (JENKINS; TIERSCH, 1997). These procedures might assure: artificial breeding in cases of asynchronous gamete production (SANCHES et al., 2011a), commercial trade of fresh semen between laboratories and companies, or maintainance of viable gametes 
from distant collection sites for further laboratory procedures in genetic conservation programs.

This study describe the seminal and spermatic characteristics on fresh semen and investigated the effects of dilution, temperature, and storage period on the sperm parameters of Steindachneridion melanodermatum semen. These data will provide information supporting the implementation and maintenance of gene banks and breeding programs focused on species conservation and aquaculture.

\section{Material and Methods}

The experiment was carried out during October 2010 at the Experimental Station of Ichthyological Studies of the Energetic Company of Paraná State, Hydroelectric Power Plant Governador Ney Braga (EEEI - Copel) in Iguaçu Reserve, Paraná, Brazil, and in the Laboratory of Reproductive Technology to Aquatic Animals (LATRAAC) at the University of Western Paraná State, Toledo, Paraná, Brazil.

The broodstock from EEEI - Copel was maintained through the year in ground tanks with concrete ledges and sandy bottoms. Water was pumped from the Salto Segredo Reservoir in the Iguaçu River to replace water lost through evaporation and infiltration. Animals were fed commercial extruded food containing 32\% raw protein at a rate of $3 \%$ of the fish weight per day. Live food (small fish) was also given to the broodstock. Nine males were selected from the broodstock $(1,857.22 \pm 774.60 \mathrm{~g})$ based on semen release after applying slight coelomatic pressure. The selected males were transferred to the artificial reproduction laboratory. They were maintained in masonry tanks coated with ceramic tiles that were equipped with constant water replenishment, and temperature control $\left(25 \pm 1^{\circ} \mathrm{C}\right)$ systems with electric heating.

To promote increased semen production, males were hormonally induced (SANCHES et al., 2010) by intramuscular inoculation with $3.0 \mathrm{mg}$ of carp hypophysis extract (CHE) per kilogram of fish.
Semen was collected after 260 hours-degree (10 $\mathrm{h}$; water temperature $26^{\circ} \mathrm{C}$ ) by massaging the coelomatic region from head to tail (LUDWIG et al., 2005) after anesthetizing the fish by immersion in water containing $75 \mathrm{mg}$ benzocaine. $\mathrm{L}^{-1}$ (OKAMURA et al., 2010). The first sperm drops were discarded to avoid urine or feces contamination (POUPARD et al., 1998). Released semen volume was measured for each specimen using graduated assay tubes with an accuracy of $0.1 \mathrm{~mL}$.

After collection, semen samples of each male were evaluated to determine seminal and sperm parameters. We evaluated sperm for: plasma osmolality (OSM), seminal $\mathrm{pH}(\mathrm{pH})$, sperm motility (MOT), curvilinear velocity (VCL), straight-line velocity (VSL), average path velocity (VAP), total time of sperm motility (TEMP), sperm concentration (CONC), and index of morphological normality of spermatozoa (NORM).

To determine OSM, $2.5 \mathrm{~mL}$ of semen was centrifuged at 3,500 rpm for $10 \mathrm{~min}$. Then, the seminal plasma was separated and stored in Eppendorf tubes in the freezer at $-20^{\circ} \mathrm{C}$. The osmolality was established by analyzing the samples using a cryoscopic method with an osmometer (PLZ, model PLZ-1000) (ALAVI et al., 2010). Seminal $\mathrm{pH}$ was determined by a colorimetric method using litmus paper (TESSARO et al., 2012). One drop of semen was placed on the paper and the color obtained was compared with the manufacturer's scale $\left(\right.$ Merk $\left.^{\circledR} ; 1-14\right)$.

Computer Assisted Sperm Analysis (CASA) was adapted to analyze $S$. melanodermatum spermatozoa movement. The analyses were carried out $10 \mathrm{~s}$ after the beginning of sperm movement (TESSARO et al., 2012). MOT, VCL, VSL, and VAP were evaluated. Sperm aliquots were activated with distilled water at a dilution of 1:50 $\mu \mathrm{L}$ (semen:water). $10 \mu \mathrm{L}$ of the diluted material was dropped onto a mirrored Neubauer's chamber and visualized using an optic microscope $\left(\right.$ Nikon $^{\circledR}$ Eclipse E200) (40X magnification), equipped with 
a video camera (Basler ${ }^{\circledR}$ a602-f). The videos were captured at $100 \mathrm{fps}$ (SANCHES et al., 2010).

Since they were correlated, the results of VCL, VSL, and VAP were grouped for principal components analysis (PCA), and the calculated index was the sperm velocity (SV) (TESSARO et al., 2012).

TEMP was analyzed with the sperm movement video until motility ceased in $100 \%$ of the cells. CONC measurement (BILLARD et al., 1995) was performed individually and in triplicates by counting sperm cells in a Neubauer's chamber using light microscopy (40X magnification) (MYLONAS et al., 1997; WIRTZ; STEINMANN, 2006). For the CONC analysis, fresh semen samples were fixed in buffered saline formaldehyde (STREIT JÚNIOR et al., 2004, 2006) at a dilution of 1:1000 (BOMBARDELLI et al., 2006).

To evaluate and measure NORM, two smears were prepared using the material previously fixed in buffered saline formaldehyde solution (RURANGWA et al., 2004). The slides containing the smears were stained in Bengal Rose (HAFEZ; HAFEZ, 2004; STREIT JÚNIOR et al., 2004) and analyzed using light microscopy (40X magnification). Four hundred spermatozoa from each sample from a single fish were evaluated and classified as normal or abnormal (CBRA, 1998; CHENOWETH, 2005; STREIT JÚNIOR et al., 2006).

Moreover, semen samples from each male were used to analyze the effects of storage periods under different conditions. This assay was performed using a randomized $2 \times 2 \times 8$ factorial design, and the experimental factors were the diluted and undiluted sperm, storage temperature, and storage time. Diluted and undiluted sperm samples were stored in Eppendorf tubes at $25^{\circ} \mathrm{C}$ (room temperature) or $10^{\circ} \mathrm{C}$. The spermatozoa quality was measured at $0 \mathrm{~h}, 5 \mathrm{~h}, 9 \mathrm{~h}, 18 \mathrm{~h}, 27 \mathrm{~h}, 36 \mathrm{~h}, 45$ $\mathrm{h}$, and $54 \mathrm{~h}$ after storage. The sperm samples were diluted in the ratio of 1:4 (1-semen:3-solution) in a solution containing 5\% fructose and 5\% milk powder. A sperm sample $(2 \mathrm{~mL})$ from a single fish was considered an experimental unit. MOT, SV, and TEMP were analyzed as described above.

Mean and standard deviation values of sperm and sperm parameters from fresh semen were calculated using STATISTICA $7.0^{\circledR}$ software. Sperm parameters after the storage assay were analyzed using a Factorial ANOVA. Finally, Duncan's multiple mean comparison test was applied. These statistical procedures were also performed using STATISTICA $7.0^{\circledR}$ software.

\section{Results}

Males of $S$. melanodermatum produced 11.74 $\pm 5.38 \mathrm{~mL}$ of semen with $1.03 \times 10^{10} \pm 0.36 \times$ $10^{10}$ spermatozoa.mL $\mathrm{mL}^{-1}$ and $75.81 \pm 5.71 \%$ normal spermatozoa. The mean values of seminal $\mathrm{pH}$ and osmolality were $7.11 \pm 0.31$ and $258.78 \pm 29.36$ mOsm. $\mathrm{kg}^{-1}$, respectively (Table 1). Immediately after sperm collection, $99.86 \pm 0.31 \%$ of spermatozoa were motile, with a $185.58 \pm 14.11 \mu \mathrm{m} . \mathrm{s}^{-1} \mathrm{VCL}$, $49.15 \pm 4.66 \mu \mathrm{m} . \mathrm{s}^{-1} \mathrm{VSL}$, and an $87.02 \pm 4.13 \mu \mathrm{m} . \mathrm{s}^{-1}$ VAP (Table 1).

The VCL, VSL, and VAP were highly correlated ( $r=0.97, r=0.99$ and $r=0.98$, respectively) and their grouping using PCA resulted in the equation: $\mathrm{SV}=0.325244 . \mathrm{VCL}+0.343368$. VAP +0.331388 . VSL. The SV estimated in fresh semen was 106.52 $\pm 4.45 \mu \mathrm{m} . \mathrm{s}^{-1}$ and the TEMP was $79.31 \pm 5.62 \mathrm{~s}$ (Table 1). 
Table 1. Seminal and sperm parameters of Iguaçu sorubim (Steindachneridion melanodermatum) males.

\begin{tabular}{|c|c|c|c|c|c|c|c|c|c|c|}
\hline \multirow{2}{*}{ Parameters } & \multicolumn{10}{|c|}{ Males } \\
\hline & \multicolumn{9}{|c|}{ Males } & \multirow{2}{*}{$\begin{array}{c}\text { Mean } \pm \\
\text { standard- } \\
\text { deviation }\end{array}$} \\
\hline Parameters & 1 & 2 & 3 & 4 & 5 & 6 & 7 & 8 & 9 & \\
\hline Volume (mL) & 11.2 & 6.8 & 7.6 & 11.4 & 17.2 & 7.2 & 13.5 & 22.8 & 8.0 & $11.74 \pm 5.38$ \\
\hline OSM (mOsm) & 217 & 276 & 208 & 277 & 303 & 254 & 246 & 264 & 284 & $258.78 \pm 29.36$ \\
\hline Seminal pH & 7 & 7 & 7 & 7 & 7 & 7 & 7 & 8 & 7 & $7.11 \pm 0.31$ \\
\hline $\begin{array}{l}\text { CONC }\left(\mathrm{x} 10^{9}\right. \\
\left.\text { cells. } \mathrm{mL}^{-1}\right)\end{array}$ & 6.58 & 7.30 & 7.18 & 17.1 & 12.4 & 7,90 & 7,28 & 14.4 & 12.6 & $10.3 \pm 3.65$ \\
\hline NORM (\%) & 71.33 & 80.00 & 78.33 & 69.67 & 73.00 & 76.33 & 66.67 & 82.67 & 84.33 & $75.81 \pm 5.71$ \\
\hline MOT (\%) & 99.00 & 100.00 & 100.00 & 100.00 & 100.00 & 100.00 & 100.00 & 99.75 & 100.00 & $99.86 \pm 0.31$ \\
\hline $\operatorname{VCL}\left(\mu \mathrm{m} \cdot \mathrm{s}^{-1}\right)$ & 158.87 & 181.93 & 167.65 & 182.92 & 203.13 & 203.13 & 185.95 & 194.27 & 192.34 & $185.58 \pm 14.11$ \\
\hline $\operatorname{VSL}\left(\mu \mathrm{m} \cdot \mathrm{s}^{-1}\right)$ & 59.60 & 50.95 & 46.53 & 44.14 & 44.82 & 49.06 & 48.78 & 45.20 & 53.26 & $49.15 \pm 4.66$ \\
\hline $\operatorname{VAP}\left(\mu \mathrm{m} \cdot \mathrm{s}^{-1}\right)$ & 92.66 & 88.13 & 80.60 & 83.75 & 83.07 & 85.98 & 88.41 & 86.52 & 94.07 & $87.02 \pm 4.13$ \\
\hline $\mathrm{SV}\left(\mu \mathrm{m} \cdot \mathrm{s}^{-1}\right)$ & 103.24 & 106.32 & 97.62 & 102.88 & 109.44 & 111.85 & 107.00 & 107.87 & 112.51 & $106.52 \pm 4.45$ \\
\hline TEMP (s) & 90.50 & 74.67 & 78.00 & 74.67 & 72.00 & 84.67 & 78.00 & 77.00 & 84.33 & $79.31 \pm 5.62$ \\
\hline
\end{tabular}

OSM - seminal plasma osmolality, CONC - sperm concentration, NORM - index of morphological normality of spermatozoa, MOT - sperm motility, VCL - sperm curvilinear velocity, VSL - sperm straight line velocity, VAP- sperm average path velocity, SV - sperm velocity, TEMP - total time of sperm motility.

Motile spermatozoa were observed immediately after semen dilution, although this finding was not quantified by CASA due to the cell high concentration. Semen dilution, time, and temperature of storage influenced $(\mathrm{p}<0.05) S$. melanodermatum sperm motility (Figure 1). No differences related to either temperature or dilution were detected up to $18 \mathrm{~h}$ of storage (Figure 1). After $27 \mathrm{~h}$ of storage, the diluted semen kept at $25^{\circ} \mathrm{C}$ has completely lost motility, while no differences in the percentage of motile spermatozoa were reported among other treatments (Figure 1). Following $36 \mathrm{~h}$ of storage, the non-diluted semen kept at $25^{\circ} \mathrm{C}$ showed a higher percentage of motile spermatozoa (Figure 1). After $45 \mathrm{~h}$ of storage, the motile spermatozoa loss remained constant, independent of temperature or dilution (Figure 1).

Sperm velocity was influenced $(p<0.05)$ by dilution, temperature, and storage period. After 5 $\mathrm{h}$ of storage, the sperm velocity in semen stored at $10^{\circ} \mathrm{C}$ was reduced in both diluted and non-diluted samples (Figure 2). At $54 \mathrm{~h}$ of storage, the samples (diluted or non-diluted) kept at $10^{\circ} \mathrm{C}$ had the highest sperm velocity (Figure 2).

The total time of sperm motility in semen of $S$. melanodermatum was affected $(p<0.05)$ by dilution, time, and temperature of storage (Figure 3). After $5 \mathrm{~h}$ of storage, the total time of sperm motility in samples stored at $10^{\circ} \mathrm{C}$ decreased when compared to fresh semen (Figure 3). Between $9 \mathrm{~h}$ and $36 \mathrm{~h}$ of storage, the time of sperm motility was maintained, except in diluted sperm samples kept at $25^{\circ} \mathrm{C}$. Diluted sperm at $25^{\circ} \mathrm{C}$ lost motility after $9 \mathrm{~h}$ of storage, and after $27 \mathrm{~h}$, they were no longer viable (Figure 3). After $54 \mathrm{~h}$ of storage, the total time of activation in diluted or non-diluted sperm maintained at $10^{\circ} \mathrm{C}$ had the highest mean value (Figure 3). 
Figure 1. Sperm motility over time in non-diluted (ND) and diluted (D) Steindachneridion melanodermatum sperm samples in solution containing $5 \%$ fructose and $5 \%$ milk powder, stored at $25^{\circ} \mathrm{C}$ or $10^{\circ} \mathrm{C}$.

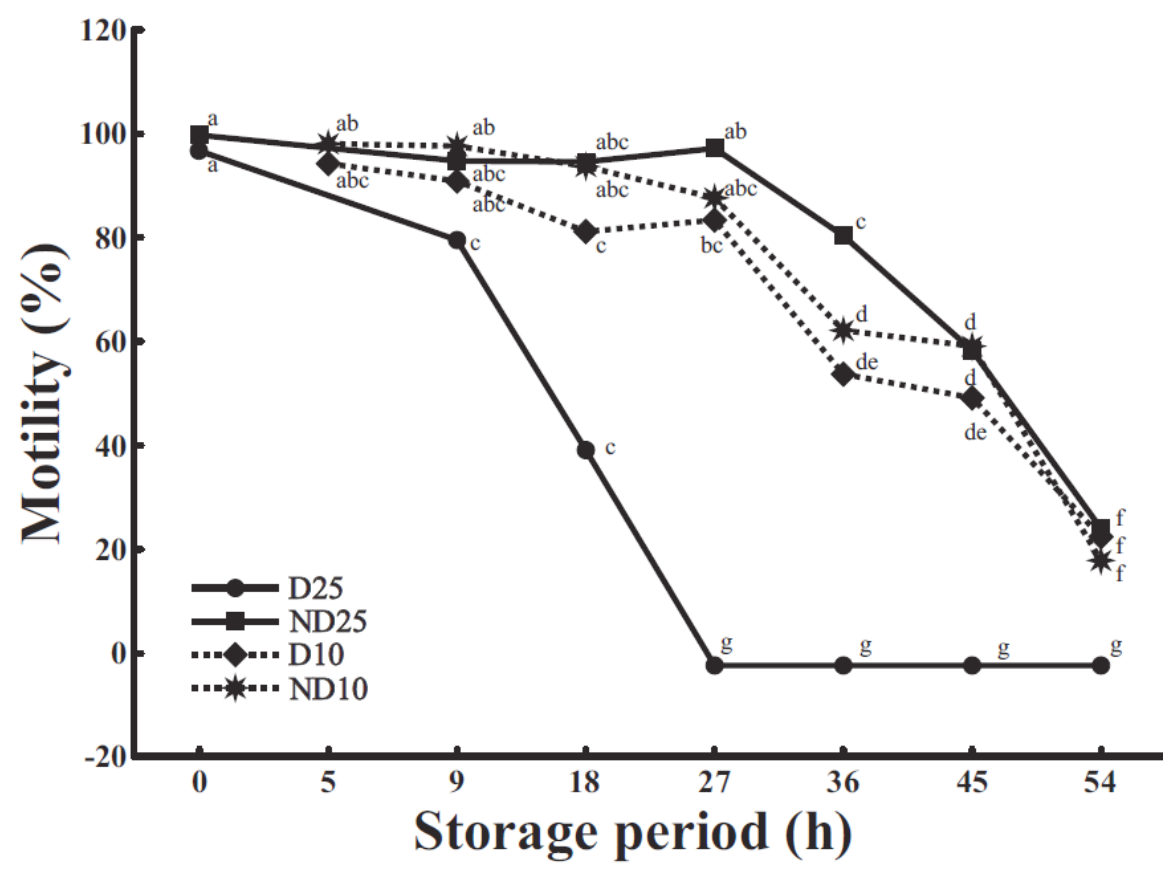

Figure 2. Sperm velocity over time in non-diluted (ND) and diluted (D) Steindachneridion melanodermatum sperm samples in solution containing $5 \%$ fructose and $5 \%$ milk powder, stored at $25^{\circ} \mathrm{C}$ or $10^{\circ} \mathrm{C}$.

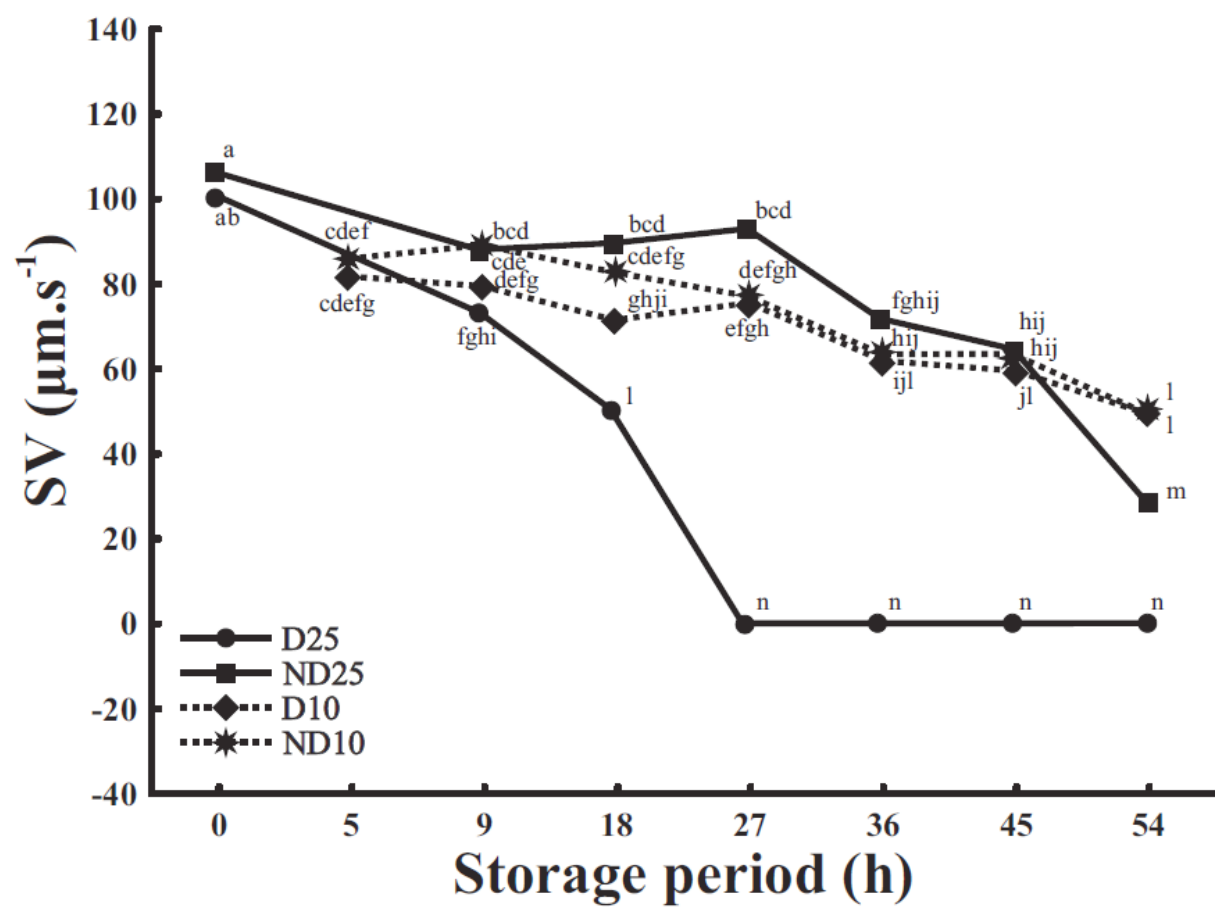


Figure 3. Total time of sperm activation for storage periods in non-diluted (ND) and diluted (D) Steindachneridion melanodermatum sperm samples in solution containing $5 \%$ fructose and $5 \%$ milk powder, stored at $25^{\circ} \mathrm{C}$ or $10^{\circ} \mathrm{C}$.

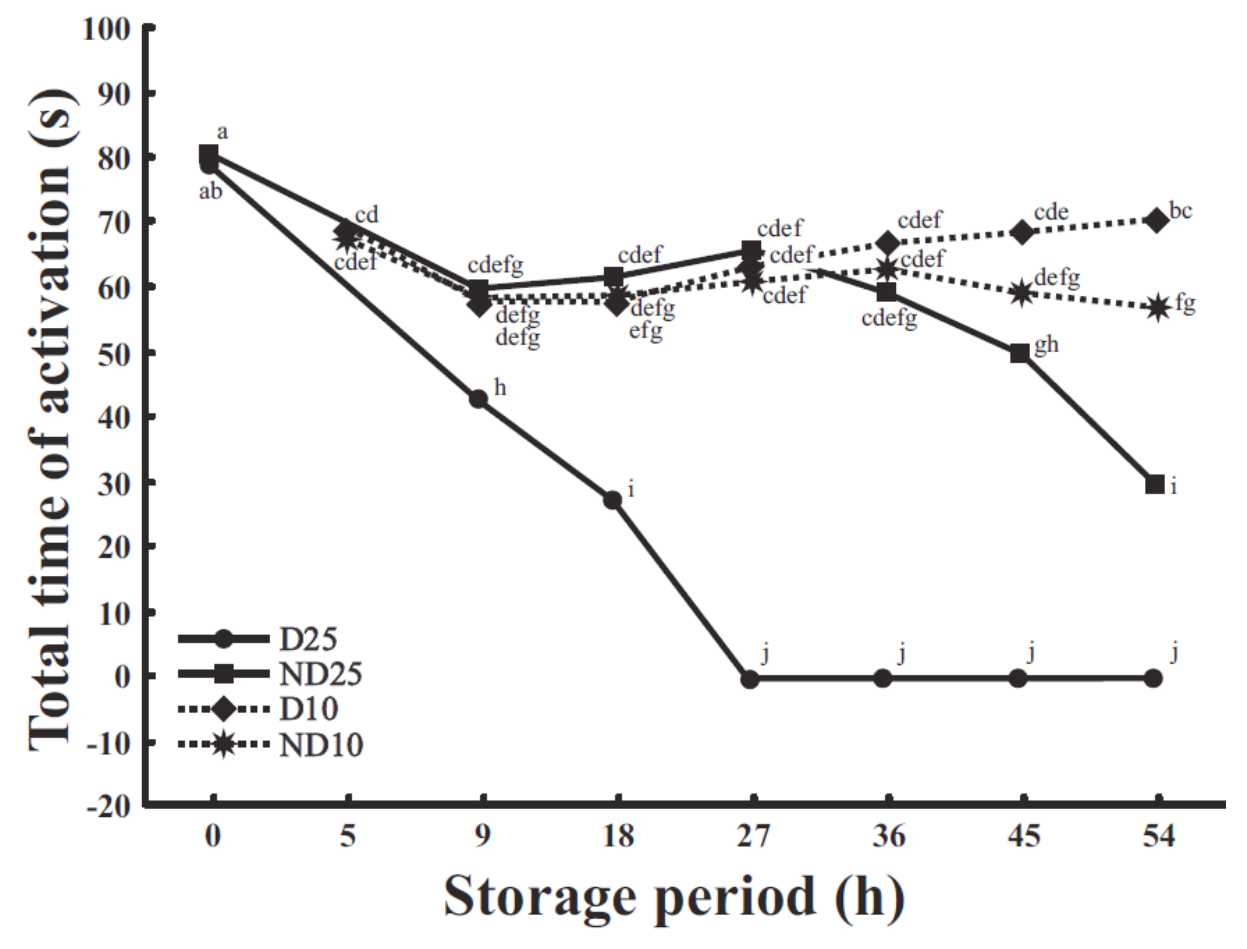

\section{Discussion}

Knowledge regarding seminal and sperm characteristics is fundamental for artificial breeding (SANCHES et al., 2011b) as it allows for optimal utilization of semen and broodstock (BOMBARDELLI et al., 2006). Although there is little information regarding the reproductive biology of the genus Steindachneridion (HONJI et al., 2012), the sperm dynamics of $S$. parahybae have been analyzed (SANCHES et al., 2013). However, information about some seminal and sperm characteristics, including volume, viscosity, coloration, sperm concentration, and time of activation are available for $S$. melanodermatum based on subjective methods (SANT'ANNA, 2009). To the best of our knowledge, the present study is the first to report the seminal and sperm characteristics of $S$. melanodermatum using computerized analysis.

The values obtained for semen volume, CONC, and TEMP differ from those reported by Sant'anna
(2009), who analyzed the sperm of 11 males in January. This author verified that males released $1.39 \pm 0.75 \mathrm{~mL}$ of sperm containing $52.20 \pm 21.58$ $\times 10^{9}$ spermatozoa. $\mathrm{mL}^{-1}$ with $154.40 \pm 72.57 \mathrm{~s}$ TEMP. These differences might be related to the season (GODINHO, 2007), as preliminary results suggest increased reproductive activity of S. melanodermatum males between September and November (unpublished data). Differences in hormonal treatment (GODINHO, 2007) can also influence semen and sperm parameters, as Sant'anna (2009) used a low dosage of carp hypophysis extract $\left(1,1 \mathrm{mg} \cdot \mathrm{kg}^{-1}\right)$ that was possibly not sufficient to stimulate suitable spermiation. Similarly, considering the direct effect of dilution on sperm activation (BILLARD; COSSON, 1992), differences in motility characteristics can be related to the method used to promote sperm activation. Sant'anna (2009) used a low dilution (1:1; sperm:water) to stimulate sperm activation, when a high dilution (1:1,000; sperm:water) is suggested 
(BILLARD; COSSON, 1992). However, the volume of sperm released $(7.63 \mathrm{~mL}$ to $10.15 \mathrm{~mL}$ ) and sperm concentration ( 2.28 spermatozoa. $\mathrm{mL}^{-1}$ to $34.68 \times 10^{9}$ spermatozoa. $\mathrm{mL}^{-1}$ ) from $S$. parahybae, obtained in the same season by the same protocol of hormonal manipulation, were similar to these verified in the present experiment (SANCHES et al., 2014).

Sanches et al. (2013) also determined the characteristics of MOT, VCL, VSL, and VAP in males of $S$. parahybae using computerized analysis. The results reported $10 \mathrm{~s}$ after sperm activation were lower than those verified in the present research for $S$. melanodermatum and showed values equal to $89.10 \%, 107.20 \mu \mathrm{m} . \mathrm{s}^{-1}, 77.10 \mu \mathrm{m} . \mathrm{s}^{-1}$, and 83.60 $\mu \mathrm{m} . \mathrm{s}^{-1}$ for MOT, VCL, VSL, and VAP, respectively. Sperm motility is considered an important aspect in fish breeding and the primary characteristic to infer sperm viability (URBANYI et al., 1999; GLOGOWSKI et al., 2002), and has been directly related to fertilization rates (FAUVEL et al., 2010). Tessaro et al. (2012) stated that sperm velocity could be associated with spermatozoa fertility, but the mechanisms for this are unknown. Computerized analyses are useful tools since they provide fast and precise data regarding sperm parameters for artificial breeding (SANCHES et al., 2011c).

Other seminal or sperm characteristics are important to determine sperm quality, as some are related to sperm motility. Previous studies on fish reproduction focusing on sperm morphology, generally showed a high percentage of abnormal spermatozoa. Similarly, the present study identified that approximately $25 \%$ of spermatozoa had morphological abnormalities. This has also been determined in other Siluriformes fish, including jundiá (Rhamdia quelen), where the morphological normality of spermatozoa ranged from $56.25 \pm$ $4.16 \%$ to $80.71 \pm 1.47 \%$ (TESSARO et al., 2012). The relationship between sperm morphology and sperm motility in mammals is established, but its role in artificial fertilization fish still needs to be elucidated (TUSET et al., 2008).
The seminal $\mathrm{pH}$ and osmolality are also important as they are directly related to the beginning or maintenance of sperm movement (ALAVI; COSSON, 2005). Hilbig et al. (2008) reported a $\mathrm{pH}$ of $8.6 \pm 0.2$ in jundiá seminal plasma. Similarly, the seminal plasma osmolality in $S$. melanodermatum was close to that reported by Farias et al. (1999) in tambaqui (Colossoma macropomum), being equivalent to $247 \pm 58 \mathrm{mOsm} . \mathrm{kg}^{-1}$ after hormonal treatment. Plasma osmolality directly affects sperm activation, after semen dilution and spermatozoa exposure to a hypotonic medium (LINHART et al., 1999).

There are no previous reports about semen storage for $S$. melanodermatum, as this is a pioneer study in this species. Sperm storage is an essential step to fish selection and synchronization of available gametes (RURANGWA et al., 2004). In general, diluted or non-diluted semen samples of $S$. melanodermatum can be stored at $10^{\circ} \mathrm{C}$ for periods as long as 27 hours without jeopardizing sperm motility. Kime et al. (1996) reported similar findings when African catfish (Clarias gariepinus) semen were diluted in several solutions and stored under refrigeration. These authors observed no reduction in sperm motility for up to 24 hours of storage, but after 48 hours, the sperm motility was significantly decreased. Rurangwa et al. (2001) also reported a decline in sperm motility after 48 hours of storage in refrigerated samples of African catfish (C. gariepinus) semen diluted in a solution containing DMSO and glycerol.

The loss of sperm motility with increased storage time has been reported by several authors (RIZZO et al., 2003; FAUVEL et al., 2010). The present study showed that when diluted in aqueous solution with $5 \%$ fructose and $5 \%$ milk powder and stored at room temperature $\left(25^{\circ} \mathrm{C}\right)$, the semen viability of $S$. melanodermatum reduced rapidly. This is likely to be related to increased sperm metabolism at high temperatures (RAVINDER et al., 1997) or the presence of microorganisms, whose growth could have been favored by the environment used to 
store sperm. Over time, the sperm motility images revealed the occurrence of other organisms (not quantified) moving with the spermatozoa. Although this has not been specifically addressed, they seem to correspond to microorganisms that have developed because of favorable conditions. This microorganism growth could reduce sperm motility. Viveiros et al. (2010) reported that the high bacterial numbers in piracanjuba (Brycon orbignyanus) semen samples diluted in $\mathrm{NaCl}$-Tris decreased the sperm motility rate from $93 \%$ to $1 \%$, whereas the bacterial population increased from $10^{4}$ UFC. $\mathrm{mL}^{-1}$ to $10^{7}$ UFC. $\mathrm{mL}^{-1}$ in diluted sperm after 8 days of storage.

The utilization of different diluents and distinct storage methods might be more effective to maintain the seminal quality of stored samples. Nonetheless, the potential toxicity of such diluents (SANCHES et al., 2011a) and their ability to maintain inactive sperm cells (VIVEIROS et al., 2009) should be taken into account. Semen storage for short periods is successful for preserving the sperm quality in Neotropical fish, as reported in piracanjuba (B. orbignyanus) sperm stored at $4{ }^{\circ} \mathrm{C}$ and diluted in a proportion of 1:3 (semen:diluent) with BTS (Beltsville Thawing Solution) and $\mathrm{KCl}$ (MURGAS et al., 2004). Similar results were found in pirapitinga ( $B$. nattereri) semen samples stored at $4^{\circ} \mathrm{C}$ to $6^{\circ} \mathrm{C}$ and diluted in a proportion of $1: 10$ (semen:diluent) with BTS (OLIVEIRA et al., 2007).

The results from the present study diverge from those reported in other species, because the diluent did not improve sperm quality. Besides the microbial activity, temperature (BILLARD et al., 1995) might have been responsible for the reduced sperm viability. The effects of storage temperature on sperm viability in $S$. melanodermatum are corroborated by the results obtained with sperm stored at $10^{\circ} \mathrm{C}$, which extended the cell viability in diluted and non-diluted sperm samples. Sanches et al. (2011a) have also suggested that storage of jundiá ( $R$. quelen) sperm under high temperatures is detrimental to sperm motility.
The sperm velocity remained constant among treatments, except for diluted semen samples stored at $25^{\circ} \mathrm{C}$, in which the viability was quickly lost. This effect might have been caused by the drop in cellular energy associated with higher metabolic activity and the limitation of energy sources (BOBE; LABBÉ, 2010). Similarly, temperature might have interfered in the extended time of sperm motility in cooled and diluted semen, once the metabolic activity of spermatozoa was reduced (BILLARD et al., 1995) thereby leading to low consumption rates of available energy supplies.

Overall, the solution comprising 5\% fructose and $5 \%$ milk powder was inadequate for dilution and storage of $S$. melanodermatum sperm. Despite the lack of previous information regarding sperm storage for this species and previous research focusing on more effective procedures, we recommend that, when necessary, non-diluted semen samples should be stored at $10^{\circ} \mathrm{C}$. Moreover, for periods as long as 27 hours, the non-diluted semen could be stored at room temperature $\left(25^{\circ} \mathrm{C}\right)$ without affecting sperm motility.

\section{Acknowledgments}

The authors are grateful to the Energetic Company of Paraná (COPEL) and the technical team from the Experimental Station of Ichthyological Studies of the Hydroelectric Power Plant Governador Ney Braga.

\section{References}

ALAVI, S. M. H.; COSSON, J. Sperm motility in fishes. I. Effects of temperature and $\mathrm{pH}$ : a review. Cell Biology International, London, v. 29, n. 2, p. 101-110, 2005.

ALAVI, S. M. H.; JORFI, E.; HATEF, A.; MORTEZAVI, S. A. S. Sperm motility and seminal plasma characteristics in Barbus sharpeyi (Gunther, 1874). Aquaculture Research, Oxford, v. 41, n. 10, p. 688-694, 2010. 
BILLARD, R.; COSSON, J.; CRIM, L. W. Sperm physiology and quality. In: BROMAGE, N. R.; ROBERTS, R. J. (Ed.). Broodstock management and egg and larval quality. London: Blackwell Science Ltd, 1995. p. 25-52.

BILLARD, R.; COSSON, M. P. Some problems related to the assessment of sperm motility in freshwater fish. Journal of Experimental Zoology, Haboken, v. 261, n. 2, p. 122-131, 1992.

BOBE, J.; LABBÉ, C. Egg and sperm quality in fish. General and Comparative Endocrinology, New York, v. 165, n. 3, p. 535-548, 2010.

BOMBARDELLI, R. A.; MÖRSCHBÄCHER, E. F.; CAMPAGNOLO, R.; SANCHES, E. A.; SYPERRECK, M. A. Dose inseminante para fertilização artificial de ovócitos de jundiá Rhamdia quelen (Quoy \& Gaimardm, 1824). Revista Brasileira de Zootecnia, Viçosa, MG, v. 35, n. 4, p. 1251-1257, 2006.

CBRA (Colégio Brasileiro de Reprodução Animal). Manual para exame andrológico e avaliação de sêmen animal. 2. ed. Belo Horizonte: Colégio Brasileiro de Reprodução Animal, 1998. 52 p.

CHENOWETH, P. J. Genetic sperm defects. Theriogenology, Philadelphia, v. 64, n. 3, p. 457468, 2005.

COWARD, K.; BROMAGE, N. R.; HIBBITT, O.; PARRINGTON, J. Gamete physiology, fertilization and egg activation in teleost fish. Reviews in Fish Biology and Fisheries, London, v. 12, n. 1, p. 3358, 2002.

FARIAS, J. O.; NUNES, J. F.; CARVALHO, M. A. M.; SALGUEIRO, C. C. M. Avaliação" In Vitro" e" In Vivo" do sêmen de Tambaqui (Colossoma macropomum) conservado a temperatura ambiente e criopreservado em água de coco. Revista Cientifica de Produção Animal, Areia, v. 1, n. 1, p. 144-148, 1999.

FAUVEL, C.; SUQUET, M.; COSSON, J. Evaluation of fish sperm quality. Journal of Applied Ichthyology, Hamburg, v. 26, n. 5, p. 636-643, 2010.

FEIDEN, A.; SIGNOR, A.; BOSCOLO, W. R.; REIDEL, A.; COLDEBELLA, A.; SIGNOR, A. A.; KLEIN, S. Morphometric and allometric relations of cage-reared Iguaçu surubim. Pesquisa
Agropecuária Brasileira, Brasília, v. 48, n. 8, p. 1154-1158, 2013.

FROESE, R.; PAULY, D. FishBase: World Wide Web electronic publication. Version (06/2014). Canada: UBS, 2014. Disponível em: <http://www. fishbase.org > . Acesso em: 8 set. 2014.

GARAVELLO, J. C. Revision of genus Steindachneridion (Siluriformes: Pimelodidae). Neotropical Ichthyology, São Paulo, v. 3, n. 4, p. 607-623, 2005.

GLOGOWSKI, J.; KOLMAN, R.; SZCZEPKOWSKI, M.; HORVATH,A.; URBANYI, B.; SIECZYNSKI, P.; RZEMIENIECKI, A.; DOMAGALA, J.; DEMIANOWICZ, W.; KOWALSKI, R.; CIERESZKO, A. Fertilization rate of Siberian sturgeon (Acipenser baeri, Brandt) milt cryopreserved with methanol. Aquaculture, Amsterdam, v. 211, n. 1-4, p. 367-373, 2002.

GODINHO, H. P. Estratégias reprodutivas de peixes aplicadas à aqüicultura: bases para $\mathrm{O}$ desenvolvimento de tecnologias de produção. Revista Brasileira de Reprodução Animal, Belo Horizonte, v. 31, n. 3, p. 351-360, 2007.

HAFEZ, B.; HAFEZ, E. S. E. Reprodução animal. 7. ed. São Paulo: Manole, 2004. 513 p.

HILBIG, C. C.; BOMBARDELLI, R. A.; SANCHES, E. A.; OLIVEIRA, J. D.; BAGGIO, D. M.; SOUZA, B. E. Efeito do chumbo sobre a fertilização artificial e incubação de ovos de jundiá cinza (Rhamdia quelen). Acta Scientiarum, Animal Sciences, Maringá, v. 30, n. 2, p. 217-224, 2008.

HONJI, R.; TOLUSSI, C. E.; MELLO, P. H.; CANEPPELE, D.; MOREIRA, R. Embryonic development and larval stages of Steindachneridion parahybae (Siluriformes: Pimelodidae) implications for the conservation and rearing of this endangered Neotropical species. Neotropical Ichthyology, São Paulo, v. 10, n. 2, p. 313-327, 2012.

JENKINS, J. A.; TIERSCH, T. R. A preliminary bacteriological study of refrigerated channel catfish sperm. Journal of the World Aquaculture Society, Baton Rouge, v. 28, n. 3, p. 282-288, 1997.

KIME, D. E.; EBRAHIMI, M.; NYSTEN, K.; ROELANTS, I.; RURANGWA, E.; MOORE, H. 
D. M.; OLLEVIER, F. Use of computer assisted sperm analysis (CASA) for monitoring the effects of pollution on sperm quality of fish; Application to the effects of heavy metals. Aquatic Toxicology, New York, v. 36, n. 3-4, p. 223-237, 1996.

LEWANDOWSKI, V.; DECARLI, J.A.; PEDRON, F. A.; FEIDEN, A.; SIGNOR, A. BOSCOLO, W. R. Meat hydrolysates in feeding of Iguaçu catfish (Steindachneridion melanodermatum). Revista Brasileira de Ciências Veterinárias, Niterói, v. 20, n. 4, p. 222-226, 2013.

\section{LINHART, O.; WALFORD, J.;} SIVALOGANATHAN, B.; LAM, T. J. Effects of osmolality and ions on the motility of stripped and testicular sperm of freshwater- and seawateracclimated tilapia, Oreochromis mossambicus. Journal of Fish Biology, London, v. 55, n. 6, p. 1344-1358, 1999.

LUDWIG, L. A. M.; GOMES, E.; ARTONI, R. F. Um método de reprodução induzida para o surubim Steindachneridion melanodermatum (siluriformes, pimelodidae) do rio iguaçu. Publicatio UEPG Ciências Biológicas e Saúde, Ponta Grossa, v. 11, n. 3, p. 23-27, 2005.

MATOSO, D. A.; SILVA, M.; CORTINHAS, M. C. S.; CESTARI, M. M.; ALMEIDA, M. C.; VICARI, M. R.; ARTONI, R. F. Two genetic stocks of Steindachneridion melanodermatum living in sympatry in nature and genetic variability of wild parents and F1 generation. Genetics and Molecular Research, Ribeirão Preto, v. 10, n. 4, p. 2606-2612, 2011.

MURGAS, L. D. S.; MILIORINI, A. B.; FRANCISCATTO, R. T.; MARIA, A. N. Spermatic viability of piracanjuba (Brycon orbignyanus) semen cooled at 4 degrees C. Revista Brasileira de Zootecnia, Viçosa, MG, v. 33, n. 6, p. 1361-1365, 2004.

MYLONAS, C. C.; GISSIS, A.; MAGNUS, Y.; ZOHAR, Y. Hormonal changes in male white bass (Morone chrysops) and evaluation of milt quality after treatment with a sustained-release GnRHa delivery system. Aquaculture, Amsterdam, v. 153, n. 3-4, p. 301-313, 1997.

OKAMURA, D.; DE ARAUJO, F. G.; VIEIRA e ROSA, P.; FONSECA DE FREITAS, R. T.;
SOLIS MURGAS, L. D.; CESAR, M. P. Effect of benzocaine concentration and fish size on anesthesia and recovery in Nile tilapia. Revista Brasileira de Zootecnia, Viçosa, MG, v. 39, n. 5, p. 971-976, 2010.

OLIVEIRA, A. V.; VIVEIROS, A. T. M.; MARIA, A. N.; FREITAS, R. T. F.; IZAU, Z. A. Sucess of cooling and freezing of pirapitinga (Brycon nattereri) semen. Arquivo Brasileiro de Medicina Veterinaria e Zootecnia, Belo Horizonte, v. 59, n. 6, p. 1509-1515, 2007.

POUPARD, G. P.; PAXION, C.; COSSON, J.; JEULIN, C.; FIREVILlE, F.; BILLARD, R. Initiation of carp spermatozoa motility and early ATP reduction after milt contamination by urine. Aquaculture, Amsterdam, v. 160, n. 3-4, p. 317-328, 1998.

RAVINDER, K.; NASARUDDIN, K.; MAJUMDAR, K. C.; SHIVAJI, S. Computerized analysis of motility, motility patterns and parameters of spermatozoa of carp following short-term storage of semen. Journal of Fish Biology, London, v. 50, n. 6, p. 1309-1328, 1997.

RIZZO, E.; GODINHO, H. P.; SATO, Y. Shortterm storage of oocytes from the neotropical teleost fish Prochilodus marggravii. Theriogenology, Philadelphia, v. 60, n. 6, p. 1059-1070, 2003.

ROMAGOSA, E.; SOUZA, B. E.; SANCHES, E. A.; BAGGIO, D. M.; BOMBARDELLI, R. A. Sperm motility of Prochilodus lineatus in relation to dilution rate and temperature of the activating medium. Journal of Applied Ichthyology, Hamburg, v. 26, n. 5, p. 678-681, 2010.

RURANGWA, E.; KIME, D. E.; OLLIVER, F.; NASH, J. P. The measurement of sperm motility and factors affecting sperm quality in cultured fish. Aquaculture, Amsterdam, v. 234, n. 1-4, p. 1-28, 2004.

RURANGWA, E.; VOLCKAERT, F. A. M.; HUYSKENS, G.; KIME, D. E.; OLLIVIER, F. Quality control of refrigerated and cryopreserved semen using computer-assisted sperm analysis (CASA), viable staining and standardized fertilization in African catfish (Clarias gariepinus). Theriogenology, Philadelphia, v. 55, n. 3, p. 751769, 2001. 
SANCHES, E. A.; BOMBARDELLI, R. A.; BAGGIO, D. M.; SYKORA, R. M. ; XAXIER, A. M. M. Características seminais do cascudopreto (Rhinelepis aspera). Revista Brasileira de Reprodução Animal, Belo Horizonte, v. 35, n. 3, p. 357-362, 2011b.

SANCHES, E. A.; BOMBARDELLI, R. A.; MARCOS, R. M.; NEUMANN, G.; TOLEDO, C. P. R.; ROMAGOSA, E. Sperm motility of Rhamdia quelen studied using computer-assisted analysis by open-source software. Aquaculture Research, Oxford, v. 42, n. 1, p. 153-156, 2010.

SANCHES, E. A.; MARCOS, R. M.; BAGGIO, D. M.; TESSARO, L.; BALEN, R. E.; BOMBARDELLI, R. A. Sperm concentration estimate of fish semen using spermatocrit method. Revista Brasileira de Zootecnia, Viçosa, MG, v. 40, n. 6, p. 1163-1167, 2011c.

SANCHES, E. A.; MARCOS, R. M.; OKAWARA, R. Y.; CANEPPELE, D.; BOMBARDELLI, R. A.; ROMAGOSA, E. Sperm motility parameters for Steindachneridion parahybae based on open-source software. Journal of Applied Ichthyology, Hamburg, v. 29, n. 5, p. 1114-1122, 2013.

SANCHES, E. A.; NEUMANN, G.; TOLEDO, C. P. R.; BOMBARDELLI, R. A.; PIANA, P. A.; ROMAGOSA, E. Temperature and storage period over spermatic parameters of jundiá, Rhamdia quelen (Quoy \& Gaimard, 1824). Aquaculture Research, Oxford, v. 44, n. 4, p. 534-541, 2011 a.

SANCHES,E.A.;OKAWARA, R.Y.; CANEPPELE, D.; NEUMANN, G.; BOMBARDELLI, R. A.; ROMAGOSA, E. Storage of Steindachneridion parahybae oocytes at different temperatures. Animal Reproduction Science, Dublin, v. 151, n. 3-4, p. 262-268, 2014.

SANT`ANNA, J. F. M. Variáveis reprodutivas do surubim do iguaçu (Steindachneridion melanodermatum) e comparação do desenvolvimento ontogenético com o jundiá (Rhamdia quelen). 2009. Dissertação (Mestrado em Biologia Evolutiva) - Universidade Estadual de Ponta Grossa, Ponta Grossa.

STREIT JÚNIOR, D. P.; RIBEIRO, R. P.; MORAES, G. V. Características qualitativas do sêmen de pacu (Piaractus mesopotamicus) após indução hormonal.
Bioscience Journal, Uberlandia, v. 22, n. 3, p. 119125, 2006.

STREIT JÚNIOR, D. P.; SIROL, R. N.; RIBEIRO, R. P.; DE MORAES, G. V.; GALO, J. M.; DIGMAYER, M. Qualitative parameter of dourado (Salminus maxillosus) semen in capitivity. Boletim do Instituto de Pesca, São Paulo, v. 34, n. 3, p. 337344, 2008.

STREIT JÚNIOR, D.P.; MORAES, G. V.; RIBEIRO, R. P.; POVH, J. A.; SOUZA, E. D.; OLIVEIRA, C. A. L. Avaliação de diferentes técnicas para coloração de sêmen de peixes. Arquivos de Ciências Veterinárias e Zoologia da UNIPAR, Umuarama, v. 7, n. 2, p. 157-162, 2004.

SUQUET, M.; DREANNO, C.; FAUVEL, C.; COSSON, J.; BILLARD, R. Cryopreservation of sperm in marine fish. Aquaculture Research, Oxford, v. 31, n. 3, p. 231-243, 2000.

SUZUKI, H. I.; BULLA, C. K.; AGOSTINHO, A. A.; GOMES, L. C. Estratégias reprodutivas das assembléias de peixes de reservatórios do Estado do Paraná e bacias limítrofes. In: WORKSHOP: PRODUTIVIDADE EM RESERVATÓRIOS E BIOINDICADORES, 2003, Maringá. Anais... Maringá: UEM, Nupelia, 2003. p. 251-257.

TESSARO, L.; TOLEDO, C. P. R.; NEUMANN, G.; KRAUSE, R. A.; MEURER, F.; NATALI, M. R. M.; BOMBARDELLI, R.A. Growth and reproductive characteristics of Rhamdia quelen males fed on different digestible energy levels in the reproductive phase. Aquaculture, Amsterdam, v. 326, n. 329, p. 74-80, 2012.

TUSET, V. M.; TRIPPEL, E. A.; MONSERRAT, J. Sperm morphology and its influence on swimming speed in Atlantic cod. Journal of Applied Ichthyology, Hamburg, v. 24, n. 4, p. 398-405, 2008.

URBANYI, B.; HORVATH, A.; VARGA, Z.; HORVATH, L.; MAGYARY, I.; RADICS, F. Effect of extenders on sperm cryopreservation of African catfish, Clarias gariepinus (Burchell). Aquaculture Research, Oxford, v. 30, n. 2, p. 145-151, 1999.

VIVEIROS, A. T. M.; ISAU, Z. A.; FIGUEIREDO, H.C.P.; LEITE, M.A. S.; MARIA, A. N. Gentamycin Controls Bacterial Growth during Refrigerated Storage of Piracanjuba, Brycon orbignyanus, 
semen. Journal of the World Aquaculture Society, Baton Rouge, v. 41, n. 1, p. 57-65, 2010.

VIVEIROS, A. T. M.; OLIVEIRA, A. V.; MARIA, A. N.; ORFAO, L. H.; SOUZA, J. C. Sensitivity of dourado (Salminus brasiliensis) spermatozoa to different cryoprotectant solutions. Arquivo Brasileiro de Medicina Veterinaria e Zootecnia, Belo Horizonte, v. 61, n. 4, p. 883-889, 2009.

WIRTZ, S., STEINMANN, P. Sperm characteristics in perch Perca fluviatilis L. Journal of Fish Biology, Oxford, v. 68, n. 6, p. 1896-1902, 2006.
ZANIBONI-FILHO, E.; MEURER, S.; SHIBATA, O. A.; NUNER, A. P. O. Catálogo ilustrado de peixes do alto rio Uruguai. Florianópolis: Editora da UFSC, 2004. 128 p.

ZANIBONI-FILHO, E.; SCHULZ, U. H. Migratory fishes of the Uruguay River. In: CAROSFELD, J.; HARVEY, B.; ROSS, C. (Ed.). Migratory fishes of South America: biology, fisheries and conservations status. Ottawa: International Development Research Center, 2003. p. 157-194. 
